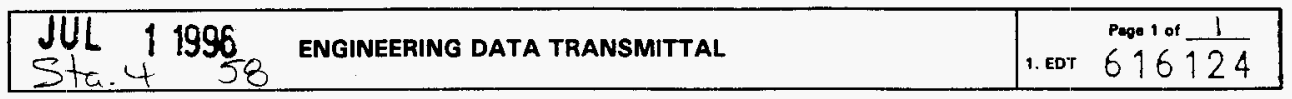

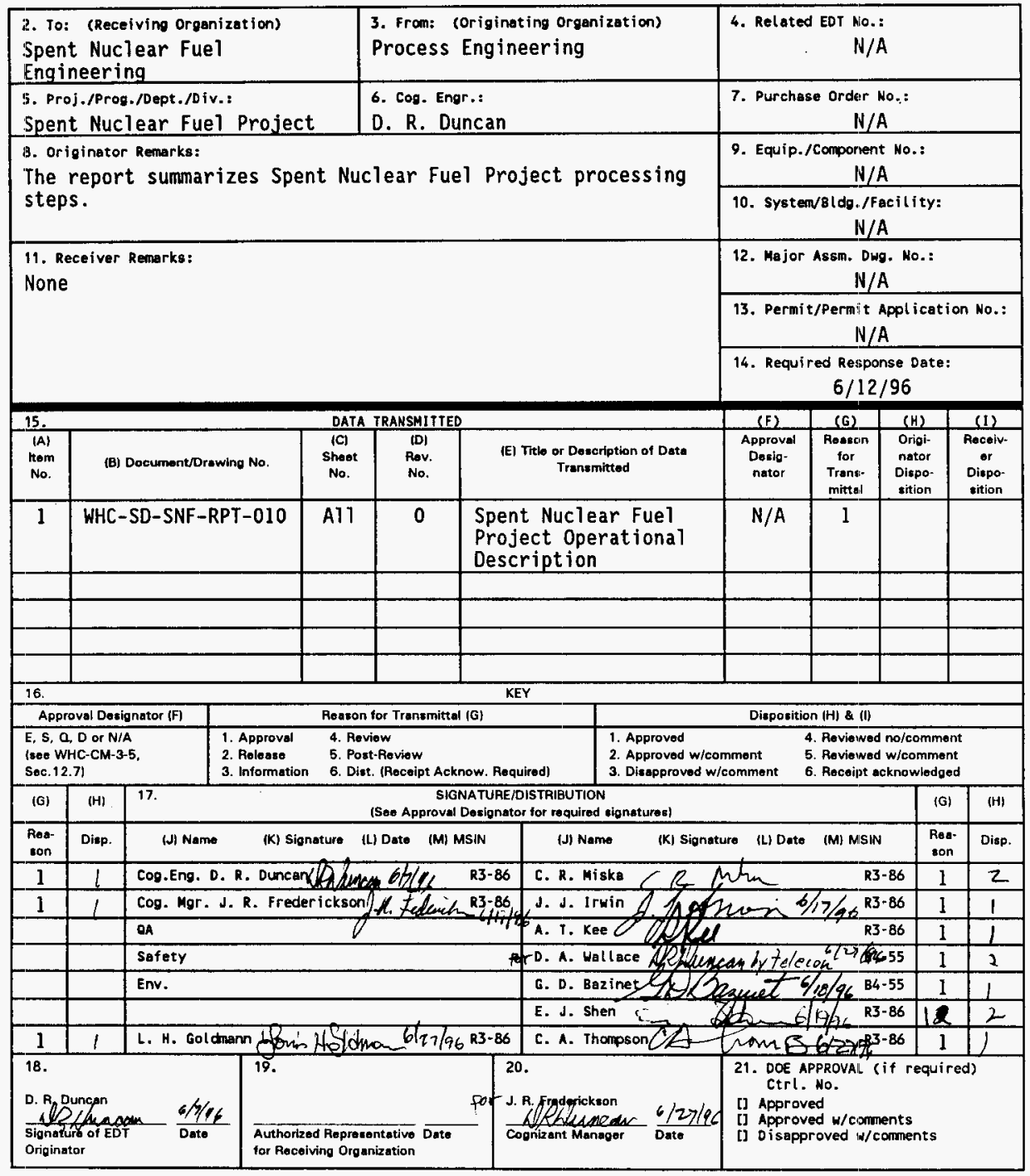

BD-7400-172-2(04/94) GEF097 


\section{Spent Nuclear Fuel Project Operational Description}

D. R. Duncan

Westinghouse Hanford Company, Richland, WA 99352

U.S. Department of Energy Contract DE-ACO6-87RL10930

EDT/ECN: 616124

UC: 600

Org Code: 2C400

Charge Code: LBOll

B\&R Code: EW-31-35-040 Total Pages: 36

Key Words: Operational Description, Process Steps, Cold Vacuum Drying, Hot Conditioning System, Canister Storage Building, Staging

Abstract: This Operational Description is prepared as input to the Multi-Canister Overpack (MCO) Pressurization Analysis. The MCO Pressurization Analysis will include topical studies and analyses on fuel/moisture/has behavior areas, modeling of temperature and pressure, and a culminating integrated gas generation and pressurization analysis providing the expected MCO pressure history for normal operating scenarios and for off-normal events.

A basis for the temperature and pressure modeling will be this operational description. Its objective is to provide time, temperature, and MCO material loading envelopes for the modeling efforts, both for normal and off-normal events.

TRADEMARK DISCLAIMER. Reference herein to any specific commercial product, process, or service by trade nante, trademark, manufacturer, or otherwise, does not necessarily constitute or inply its endorsement, recommendation, or favoring by the United States Government or any agency thereof or its contractors or subcontractors.

Printed in the United States of America. To obtain copies of this document, contact: HHC/BCS Document Control Services, P.0. Box 1970, Mailstop H6-08, Richland WA 99352, Phone (509) 372-2420; Fax (509) 376-4989.
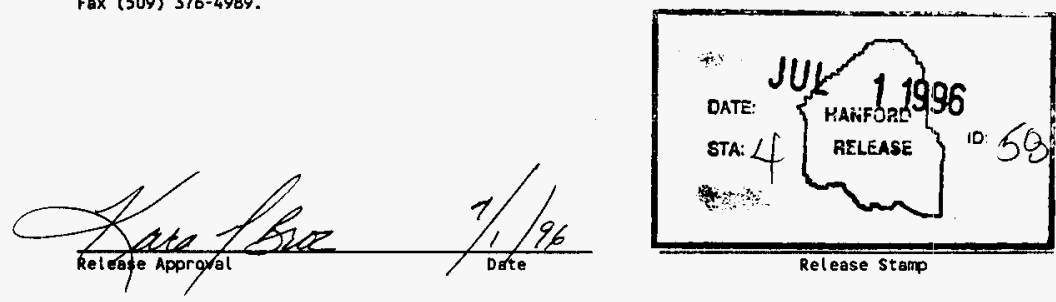

Approved for Public Release 
WHC-SD-SNF-RPT-010, Revision 0

Tabie of Contents

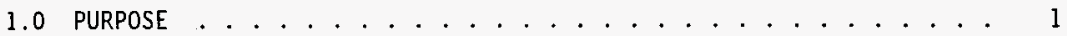

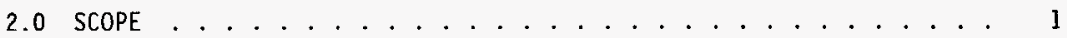

3.0 OPERATIONAL DESCRIPTION ................. 3

3.1 FUEL RETRIEVAL . . . . . . . . . . . . . . . . . . . 3

3.2 MCO/CASK PREPARATIONS $\ldots \ldots \ldots \ldots$

3.3 FUEL LOADING INTO MCO ................... . . . . 7

3.4 TRANSPORT TO THE COLD VACUUM DRYING FACILITY ....... 8

3.5 COLD VACUUM DRYING . . . . . . . . . . . . . . . 8

3.5 .1 MCO Closure ................. . . 9

3.5 .2 Cold Vacuum Drying Process .......... . . 9

3.6 TRANSFER TO THE CANISTER STORAGE BUILDING $\ldots \ldots \ldots$

3.7 STAGING . . . . . . . . . . . . . . . . . . . . . . 14

3.8 HOT CONDITIONING SYSTEM . . . . . . . . . . . . . . . 15

3.9 INTERIM STORAGE . . . . . . . . . . . . . . . . . . . . . . 16

4.0 UPSETS AND ACCIDENTS . . . . . . . . . . . . . . . . 16

4.1 TRANSFER FROM K BASINS TO THE COLD VACUUM DRYING FACILITY . . 18

4.2 COLD VACUUM DRYING FACILITY . . . . . . . . . 18

4.3 SHIPPING TO THE CANISTER STORAGE BUILDING . . . . . . . . . . 18

4.4 STAGING AT THE CANISTER STORAGE BUILDING . . . . . . . . . . . . . . 19

4.5 HOT CONDITIONING SYSTEM . . . . . . . . . . . . . . . . 19

4.6 INTERIM STORAGE AT THE CANISTER STORAGE BUILDING . . . . . 20

APPENDIX A . . . . . . . . . . . . . . . . . A

Figure 1 TN-WHC Cask Transportation System Arrangement Drawing . . . . 5

Figure 2 MCO She11 Assembly .................. 6

Figure 3 cold Vacuum Drying Process Time . . . . . . . . . . . 10

Figure 4 cold Vacuum Drying Process Time ............. 11

Figure 5 Hot Conditioning System Process Time .......... 17 
WHC-SD-SNF-RPT-010, Revision 0

OPERATIONAL DESCRIPTION

\subsection{PURPOSE}

This Operational Description is prepared as input to the Multi-Canister Overpack Pressurization Analysis Task. A multi-canister overpack (MCO) pressurization analysis is being performed as part of a commitment from a Value Engineering Study of January 23-26. That study evaluated vented/sealed staging of MCOs. The MCO Pressurization Analysis will include topical studies and analyses on fuel/moisture/gas behavior areas (e.g. drying, gettering), modeling of temperature and pressure, and a culminating integrated gas generation and pressurization analys is providing the expected Mco pressure history for normal operating scenarios and for off-normal events.

$A$ basis for the temperature and pressure modeling will be this operational description. Its objective is to provide time, temperature, and MCO material loading envelopes for the modeling efforts, both for normal and off-normal events.

The Spent Nuclear Fuel Project design is dynamic and is evolving. The operational description presented in this report is that current at time of preparation. The operational description will be updated periodically until the MCO Pressurization Analysis is complete, and updated afterward as appropriate.

\subsection{SCOPE}

The operating analysis will be built upon existing documentation to the extent possible:

WHC-SD-SNF-TA-008, "Spent Nuclear Fuel Process Initial Project Dose and Resource Assessment"

- Level 1 Process Flow Diagrams

- WHC-S-0426, Rev. 1 "Performance Specification for the Spent Nuclear Fuel Multi-Canister Overpack"

WHC-SO-SNF-OCD-001, "Spent Nuclear Fuel Conditioning Product Criteria"

WHC-SD-SNF-RPT-008, "Multi-Canister Overpack Failure and Recovery Study" 
WHC-SD-SNF-RPT-010, Revision 0

WHC-SD-SNF-CDR-003, "Conceptual Design Report for Cold Vacuum Drying"

WHC-SD-TP-SARP-017, "Preliminary Safety Analys is Report for Packaging (Onsite) Multiple Canister Overpack Cask (Draft)"

- Transnuclear Inc. Report E-14573, "Preliminary Design Analysis Report for the TN-WHC Cask and Transportation System"

- WHC-SD-SNF-PSE-002, Rev. 1, "Spent Nuclear Fuel Project Canister Storage Building Preliminary Safety Evaluation (Draft)"

- WHC-SD-SNF-OCD-003, "Systematic Endpoint Criteria Development by Success Tree Analys is (Draft)"

- WHC-SD-TP-RPT-004, "Environmental Conditions for On-Site Hazardous Materials Packages"

WHC-SD-SNF-RPT-002, "Multi-Canister Overpack Closure Operations Location Study"

- WHC-SD-SNF-PSE-003, "Preliminary Safety Evaluation for the Spent Nuclear Fuel Project's Cold Vacuum Drying System"

- L/B-SD-SNF-RPT-05, "Fuel Retrieval Sub-Project Options Study"

The scope of the operations analysis will be from fuel retrieval, through MCO loading, to Cold Vacuum Drying, to staging in the Canister Storage Building, to the Hot Conditioning System, and interim storage in the CSB for 40 to 75 years.

The project baseline at this point is closure of MCOs within Colld Vacuum Drying. The closure may be welding or by mechanical means.

The times and nomenclature for specific operational steps were taken from the March 22, 1996 update of WHC-SD-SNF-TA-008 and updated by the subproject conceptual designs as available.

The format of the operations analysis is:

1) A narrative description of process steps,

2) Descriptions of off-normal events including upsets and accidents either expected to occur or else significant and credible enough to require analysis by SNF Project,

3) An accompanying table with process step, duration of step (with effects of off-normal events), temperature during process step, 
WHC-SD-SNF-RPT-010, Revision 0

4) Graphical representation of time-temperature parameters for normal process steps.

Meteorological parameters for ambient environmental conditions of interest for operational steps may be found in WHC-SD-SNF-RPT-004.

\subsection{OPERATIONAL DESCRIPTION}

\subsection{FUEL RETRIEVAL}

Prior to processing, fuel campaigns are developed based upon fuel type and condition. The intent of the pre-planning is to support accountability, allow for an ALARA review of the work plans, perform characterization testing if required, minimize impact to production, and generally assess man loading, schedule, and impact to other basin activities.

The fuel is retrieved from the main basin and transferred to the process staging area in $K$ East and the decapping station in $K$ West. All fuel transfers in the basin will be accomplished using the existing basin monorail system. Fuel is retrieved and staged on a batch basis as required to support process throughput and for ALARA considerations.

Prior to transfer to the process staging are, the sealed canisters in $K$ West must be opened to allow the fuel removal to proceed. The canisters are opened in the decapping station which includes the following process steps:

- Contain and dispose of contaminated gases

- Remove canister cap

- Contain and dispose of contaminated water

In order to facilitate fuel removal and minimize sludge proliferation, al1 canisters will be subjected to a water flush and mechanical agitation process (both basins). This will be performed in a confinement enclosure in order to minimize impacts to basin water quality while removing gross sludge and separating stuck Spent Nuclear Fuel (SNF) elements, pieces, fragments, and non-fuel debris from the canister. Removing gross sludge from the canisters reduces the impact on water clarity during subsequent removal of the fuel from the canisters at the tipping station. Additionally, it facilitates visual inspection of the container to verify SNF removal. Fuel bits are collected in a bit basket and transferred to a scrap basket. STudge (which has been defined as material less than $1 / 4$ " in size) is transferred to the water treatment system.

Cleaning of fuel will occur in two stages, beginning with an end-forend tumbling of the fuel within the canister at approximately 1-2 revolutions 
WHC-SD-SNF-RPT-010, Revision 0

per minute. The fuel is then removed from the canister into a basket where it is washed with a side-to-side motion.

At the sort and inspection station, the inner and outer fuel elements are separated from each other to accommodate inspection of the individual pieces by remotely operated manipulator systems. The separated elements will be returned to the work surface for further processing. Following disassembly, the largely intact fuel elements will be picked from the work surface and placed into an inspection cradle.

At this point, a decision can be made to pass the element forward for loading into an MCO basket. Alternatively, the operator may route the fuel off-line for secondary cleaning. The operator must then deal with fragmented elements on the table. These will be inspected and collected as bits and loaded into a bits basket for loading into a scrap basket. Pieces 3 " or less in every dimension will be designated as bits.

The fuel assemblies and fuel bits that meet the required level of cleanliness are loaded into an MCO basket. The operator uses the manipulator dedicated to basket loading located in the disassemble, sort, an inspection station to pick and place individual fuel elements into a staged MCO basket. The fuel bits will be placed within and MCO scrap basket using the basket loading manipulator. Fuel assemblies and scrap will be loaded into separate MCO baskets. The loaded and inspected MCO baskets will be transferred to the MCO loading queue.

The $\mathrm{K}$ Basin Fuel Retrieval PFD's are depicted on H-1-81159, H-1-81160, $\mathrm{H}-1-81164$ and $\mathrm{H}-1-81165$.

\subsection{MCO/CASK PREPARATIONS}

Casks and empty MCOs are prepared at the Canister Storage Building for shipment to the Basins. The transportation system arrangement drawing (H-181533) is shown as Figure 1. The MCO shell assembly drawing, $\mathrm{H}-2-826303$, is 


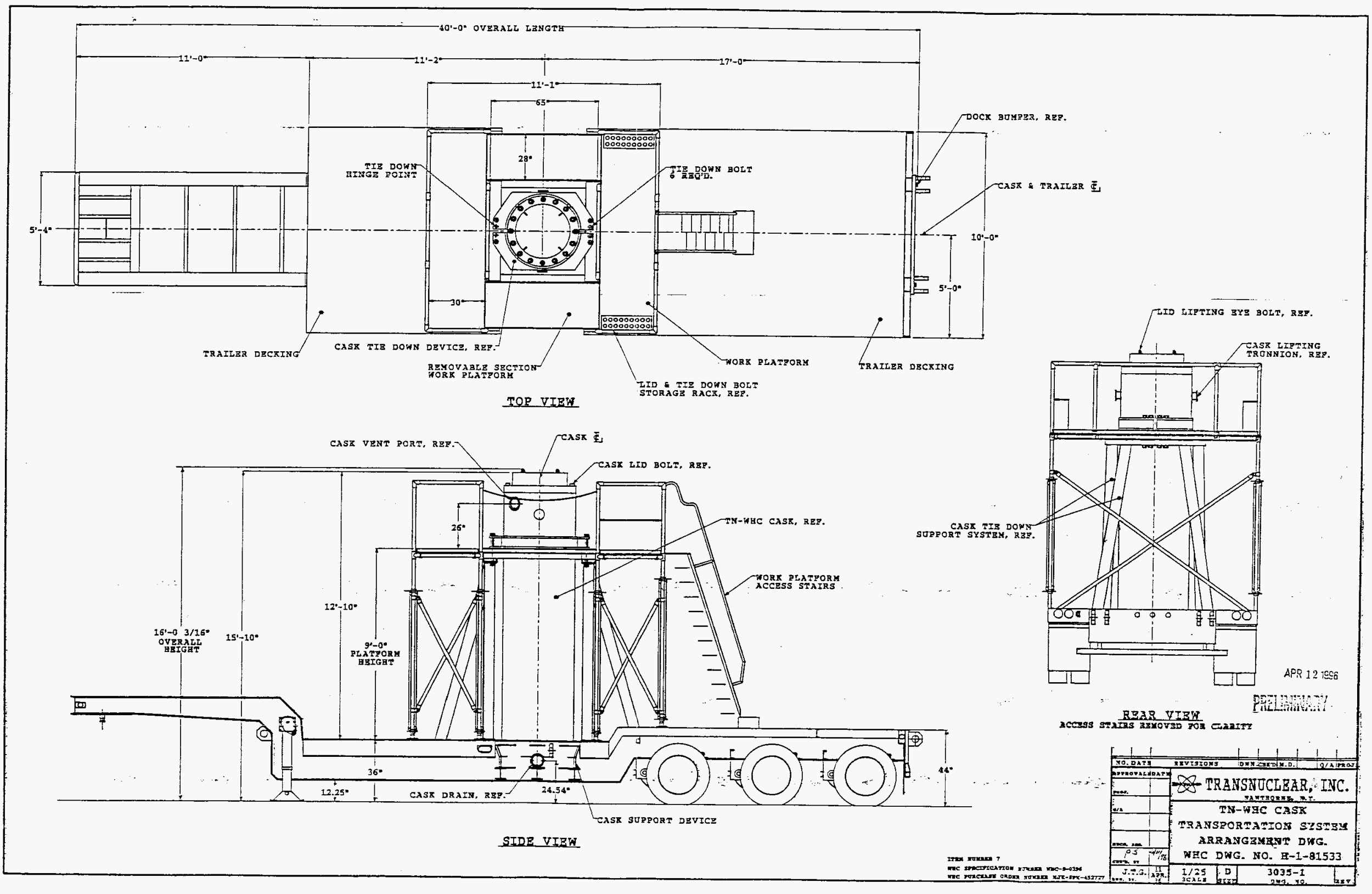




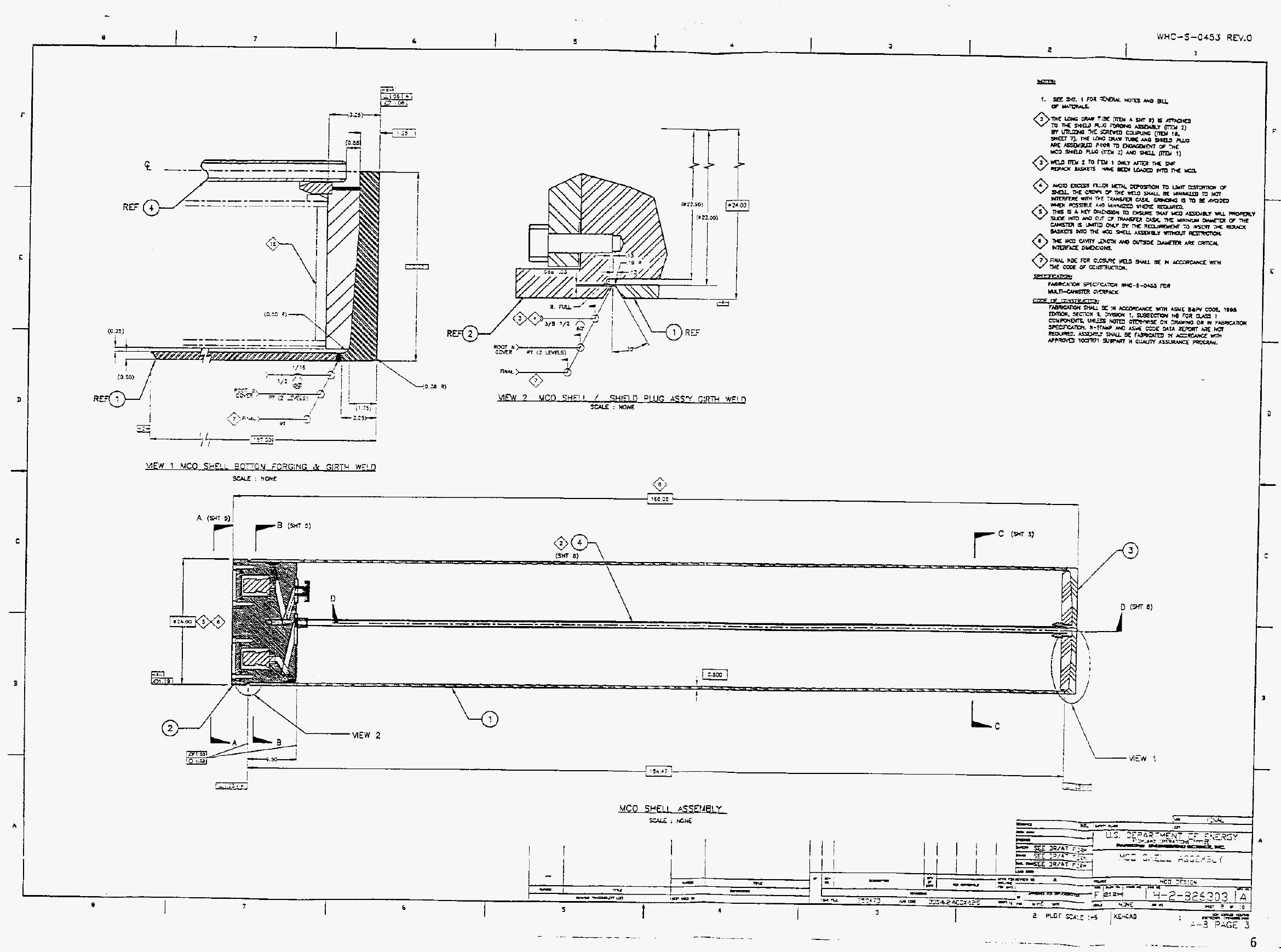


given as Figure 2. The $K$ Basins loadout pits are prepared for cask and trailer receipt. The conveyance trailer is backed into the facility and the tractor is removed. The immersion pai?, a steel structure which encloses the entire cask in a cavity which is filled with clean, demineralized water, is suspended from a work platform partially within the basin loadout pit. The cask with MCO is lifted from the trailer using the facility crane and lowered into the immersion pail. The MCO, immersion pail, and cask are filled with clean deionized water to within one inch of the top of the pail structure. The immersion pail lid is installed and inflatable seals energized. Clean deionized water is added while purging air to completely fill the pail cavity. The immersion pail and MCO/Cask are then lowered to the bottom of the loadout pit.

\subsection{FUEL LOADING INTO MCO}

Prior to commencing loading operations, the availability of a processing station within the Cold Vacuum Drying Facility to receive the MCO when loading is complete will be verified.

The MCO fuel basket Toading system includes equipment that precludes damage to the MCO sealing surfaces during the MCO loading operation. Reracked fuel, in the MCO baskets, is staged in the MCO loadout queue located just outside of the loadout pit transfer channel. The baskets are retrieved from the queue and moved underwater into the loadout pit. They are then loaded into the submerged MCO. The loading queue is a rack where the fueled baskets are staged prior to loading into the MCO. The number of fuel baskets loaded into the MCO varies with fuel type.

Assembities per MCO are as follows:

$\begin{array}{ll}\text { MkIA rerack fuel and scrap baskets } & 6 \text { high with max. of } 288 \text { Fuel } \\ & \text { Assemblies } \\ \text { MkIV rerack fuel and scrap baskets } & 5 \text { high with max. of } 270 \text { Fuel } \\ & \text { Assembiies } \\ \text { Single pass reactor fuel } & 10 \text { high }\end{array}$

The MCO is filled with only one type of the above baskets, with the exception of scrap baskets. Scrap baskets will occupy the bottom, top, or both top and bottom basket positions in the MCO. There will not be more than two scrap baskets per MCO. Handling and processing details of single pass reactor fuel are still to be determined; it will probably be the last spent fuel removed from the $K$ Basins.

Critically safe geometry $\left(K_{\text {eff }} \leq 0.945\right)$ is maintained within the MCO assembly by basket and MCO design. The MCO shell provides a critically safe geometry for Mark IV fuel and both the basket design and MCO shell design provide critically safe geometry control for Mark iA fuel. 
WHC-SD-SNF-RPT-010, Revision 0

After loading is complete the payload is gauged inside the MCO to make sure the fuel is at an acceptable level to allow for the shield plug to be reliably inserted and seated into the MCO neck. After verification, the fully assembled shield plug is inserted into the MCO and the MCO loading equipment is removed.

Following successful insertion of the shield plug assembly, the MCO/Cask system is raised to the top of the loadout pit. Exposed surfaces are rinsed with clean water to remove potential contamination and process 1 ines are connected to the MCO shield plug. The process lines are used to create a gas head space by drawing the water out of the MCO through the short shield plug dip tube, and allowing gas to enter the MCO through the long dip tube.

If the MCO has a bolted closure configuration rather than a weld, this will be accomplished at this point. If the MCO is mechanically closed, it will be accomplished with a multi-piece assembly where the shield plug is held in place by a threaded locking ring placed in the MCO neck after the shield plug is inserted. Once assembled, jacking bolts in the locking ring are tightened into the shield plug to compress the seal between the MCo shell and the shield plug.

When the proper water level is established in the MCO, the process lines are disconnected, the immersion pail lid is removed, and the cask lid is installed. The cask is then lifted from the immersion pail and allowed to drip dry over the Toadout pit. The cask surface is surveyed for contamination and the cask is then secured on the conveyance.

The MCO which will probably be vented, within the sealed cask is then ready for transport. Approximately 250 pounds of deionized water remains within the cask/MCO annulus.

\subsection{TRANSPORT TO THE COLD VACUUM DRYING FACILITY}

Prior to transport of the MCO/Cask to the CVD the $\mathrm{K}$ Basin East or West Operations shift manager shall receive permission from the CVD Operations shift manager that a drying station is available, operational and ready to receive a MCO/Cask Transporter. The cask and conveyance are surveyed for both loose contamination and fixed source to verify that the system is in compliance with the SARP requirements. Once compliance is verified, the cask is transferred to the CVD.

The Cask Transport PFD is depicted on H-1-81168.

\subsection{COLD VACUUM DRYING}

The $K$ Basin SNF Vacuum Drying Facility serves both $K$ west and $K$ East MCO shipments. The process, facility, and equipment are described in the 


\section{WHC-SD-SNF-RPT-010, Revision 0}

Conceptual Design Report, WHC-SD-SNF-CDR-003. The CVD PFD is depicted on H-181166 .

The MCO/Cask transporter is driven to the door of one of the six process bays, selected by the CVD control room, of the CVD Facility. An "elephant trunk" exhauster is connected to the truck exhaust pipe to remove diesel

fumes, the bay door is opened and the truck is positioned within the bay. The conveyance is disconnected from the tractor and the CVD bay door is closed. The conveyance is secured in the facility by dumping the air in the air ride suspension and allowing the conveyance to settle on the trailer frame supports.

A group of receiving/inspection activities is next performed to verify that the MCO is properly labeled so that SNM accountability is maintained; to verify that there is no removable contamination on the exposed surfaces of the cask or MCO; and to assay the radiation field in the vicinity of the cask and MCO top where workers will be present. Decontamination and resurvey will occur if contamination is found.

\subsubsection{MCO Closure}

If the MCO is welded, after decontamination of the fixture and MCO surfaces, the welding machine is brought in with the gas and electric cables and indexed to the MCO shield plug to weld the plug to the MCO containment shel1. Closure welding would be accomplished in five weld passes using the gas/tungsten arc process, with one non-structural root weld pass, three intermediate weld passes, and one final weld pass. The MCO closure weld is a partial penetration field weld of a full penetration double J-joint preparation; the root weld is not considered as part of the structural weld. Weld repairs are performed by manual grinding and manual welding. Weld examinations are fimited to dye penetrant testing of the non-structural root weld and dye penetrant testing of the final pass of the closure weld.

\subsubsection{Cold Vacuum Drying Process}

Figures 3 and 4 summarize the CVD process times and temperatures. Figure 3 represents process time for a mechanical closure and Figure 4 for welded closure. The MCO cold vacuum drying process is described as follows:

After the conveyance is secured, the cask lid removed, and the $\mathrm{MCO} / \mathrm{cask}$ are determined to be free of contamination, activities will include: attaching and activating some radiation monitoring instrumentation to the conveyance platform; attaching water hoses to the cask ports; swinging in an overhead boom that carries a local exhaust hood and the process connection spools; attaching the process hoses to the MCO top ports; and the HEPA vent filter is connected to the overhead boom. 


\section{COLD VACUUM DRYING PROCESS TIME}

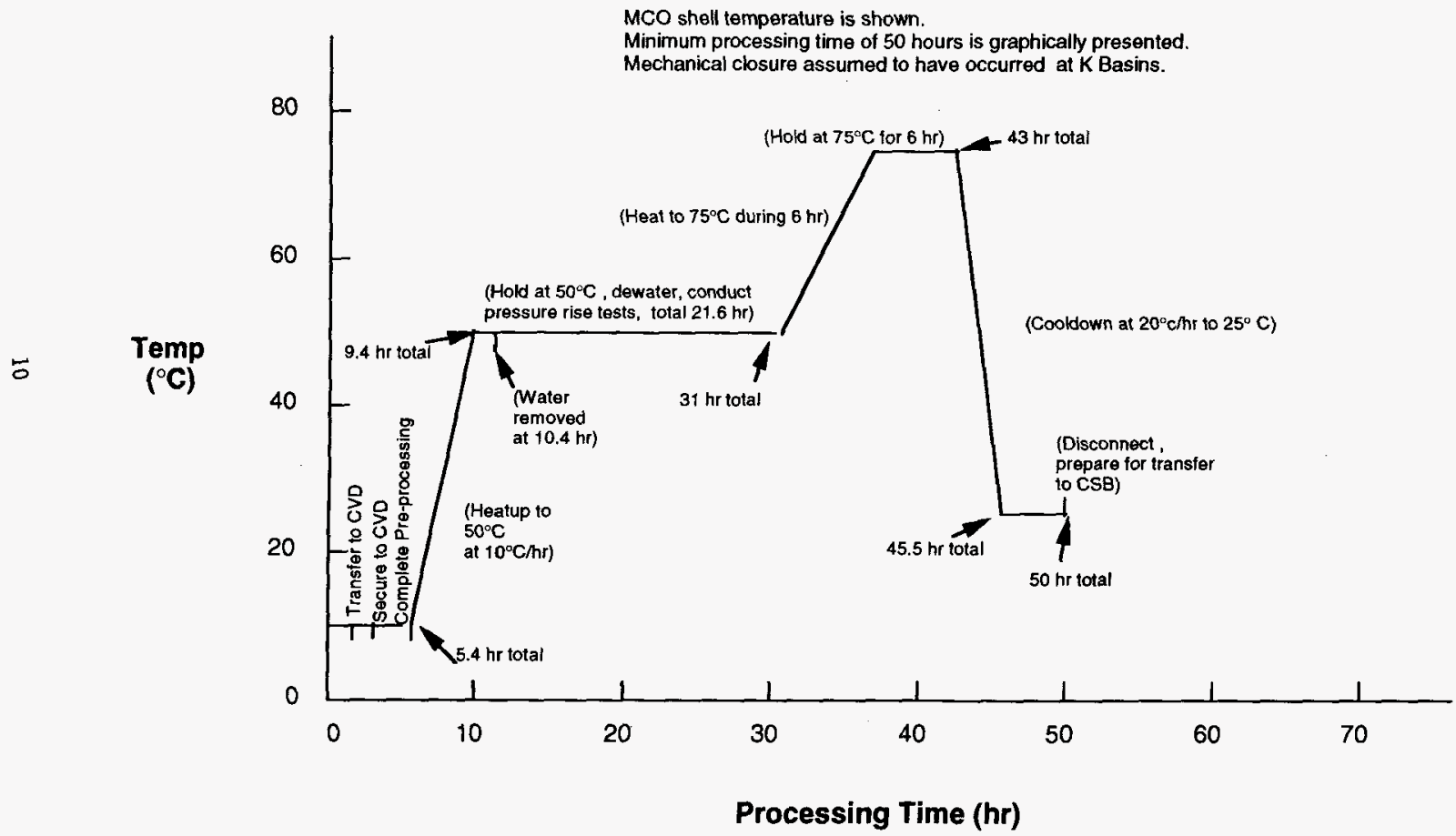




\section{COLD VACUUM DRYING PROCESS TIME}

MCO shell temperature is shown.

Minimum processing time of 63.9 hours is graphically

presented.

Welded closure assumed prior to pre-processing steps.
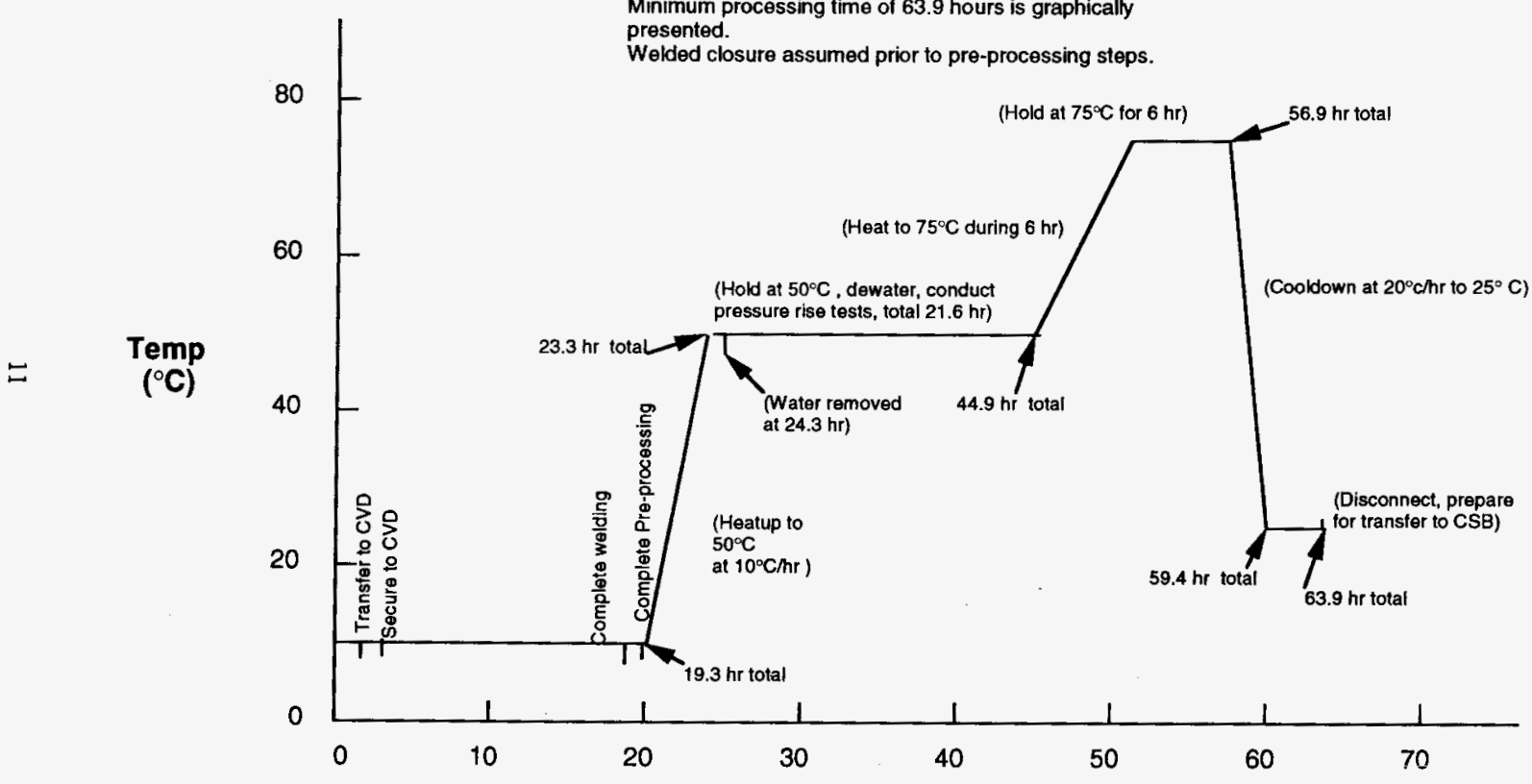

Processing Time (hr) 
WHC-SD-SNF-RPT-010, Revision 0

- The MCO/Cask annulus water heating/cooling system is connected and a water outlet temperature of $50^{\circ} \mathrm{C}$ is achieved. This achieves a hot standby condition for the fuel which would allow a quicker drying cycle. The heatup rate of $10^{\circ} \mathrm{C} / \mathrm{hr}\left(18^{\circ} \mathrm{F} / \mathrm{hr}\right)$ is achieved by circulating heated water at the rate of $20 \mathrm{gpm}$ in the annulus. If interruption of the normal processing sequence is required for any reason, the ability to cool the MCO to $10^{\circ} \mathrm{C}$ will be provided. Note, MCO/Cask heatup is not allowed until the ventilation and MCO process penetrations are connected.

- The initial removal of the bulk water from the MCO is by inert gas (nitrogen) purging and/or suction pump (nominal removal rate shall be $10 \mathrm{gpm})$. The pump will be oil-free. The bulk water is drained to the drying station contaminated water storage tank. Water will be removed to a preset limit of approximately $90 \%$ of the total volume, followed by a 20 minute hold period for drainage from the MCO internal structure. Water removal will then continue to remove the remaining $10 \%$ of the volume. Following bulk water drain the MCO will be purged with nitrogen at the rate of 3 to 5 scfm. This step will partially dry the fuel and sweep loose particulates into the internal MCO filter. The residual water removed by the vacuum system is collected in a condenser and then drained to the drying station contaminated water storage tank.

- Following the drain and purge operation there is still free water left on the internal surfaces of the MCO and surfaces of the SNF elements. Also a small heel, approximately 10 liquid ounces of water, is left at the lower end of the axial dip tube.

The MCO will then be evacuated for 90 minutes by the vacuum pump system. If the pressure is less than 75 torr at that time, pumping will be continued until the pressure reaches 0.5 torr (nominally 17 hours). If the pressure is not less than 75 torr, the purge and evacuate process will be repeated until the pressure/time set-point of 75 torr is achieved. As the MCO was being heated, the vapor pressure of water in the MCO increased to a minimum of 92.5 Torr at $50^{\circ} \mathrm{C}$. During the evacuation period a combination of a nitrogen purge and a throttle valve adjustment is maintained to prevent the pressure from being lower than 5 Torr to mitigate water freezing.

- To satisfy an initial drying criteria, a water vapor pressure of less than 3 Torr is required during a 1 hour hold period with the vacuum system isolated. An automatic pressure rise test is carried out by closing valves to isolate the MCO and monitoring the pressure. The duration will be approximately 15 minutes. The CVD control system will then predict the pressure if the test were extended an additional 45 minutes. If the prediction is 3 torr or less the hold period is continued for 45 minutes. If the 


\section{WHC-SD-SNF-RPT-010, Revision 0}

prediction is greater than 3 torr, or the pressure is greater than 3 torr after the 45 minute hold period, the evacuation cycle is repeated.

- An acceptance determination of the MCO will be made based on the pressure/temperature history. If unacceptable the MCO will be evacuated and the 1 hour hold test will be repeated.

- A final processing step of a slow ramp $\left({ }^{\circ} 4^{\circ} \mathrm{C} / \mathrm{hr}\right)$ to $75^{\circ} \mathrm{C}$ will be performed to ensure that fuel reactions occurring during subsequent sealed transport, at $75^{\circ} \mathrm{C}$ or 70 wer, will be no more rapid than those during Cold Vacuum Drying where pressure monitoring and venting capabilities are available. A six hour hold at $75^{\circ} \mathrm{C}$ will take place to ensure thermal equilibrium of the MCO.

- The MCO is then backfilled with helium and slightly pressurized to 3 psig. Cold water is pumped into the annular space within the cask to cool the MCO to $25^{\circ} \mathrm{C}$. More helium will be added as necessary to maintain a 3 psig pressure.

- The Cask and MCO is prepared for shipping by; removing the MCO process lines, surveying/decontaminating the top of the MCO, replacing the cask 1 id, and draining and drying the cask/MCO annulus. A leakage rate test on the package, if required, is performed by evacuating the cask annulus and then sampling the annulus for the leakage rate test gas. Current SARP provisions do not require a leak test.

- The drained water from the MCO, Cask annulus and vacuum system condenser is collected in the contaminated water storage tank. The water is periodically removed by tanker truck and transferred to the Tank Waste Retrieval System.

- Following completion of the package preparations, the CVD bay door is opened and the conveyance is reconnected to the tractor. The air ride suspension is energized, trailer jacks retracted, and the system is removed from the CVD.

- Prior to transfer of the MCO/Cask to the CSB the CVD Operations shift manager shall receive verification from the CSB Operations shift manager that the CSB is available, operational and ready to receive a $\mathrm{MCO} /$ Cask package and conveyance. 
WHC-SD-SNF-RPT-010, Revision 0

\subsection{TRANSFER TO THE CANISTER STORAGE BUILDING}

The Canister Storage Building PFD is depicted on $\mathrm{H}-2-825869$.

The sealed cask is transferred in a vertical orientation on the conveyance. The conveyance enters the CSB loading bay and is disconnected from the tractor. The tractor exits the loading bay and the loading bay door is closed. The sealed cask containing the MCO is unloaded by the service bay crane and placed into the service pit. The service pit portable containment tent is positioned over the service pit prior to unbolting and removing the cask lid. The MCO flanges are unbolted and removed, allowing the MCO venting and MCO inert gas purging activities to proceed. once purging is completed, the purge and vent lines are disconnected from the quick disconnects, the rupture disc remains active with flange removed, and the MCO HEPA filter remains open as a vent.

The service pit ventilation hood is repositioned away from the service pit and the MCO Handing Machine (MHM) is moved over the MCO. The MHM may be inerted at this time or later if required. The MHM isolation valve is opened. The MHM grappling mechanism mates with the MCO grapple fixture, and the MCO is withdrawn into the MHM. The MHM isolation valve is then closed and the internal spaces of the MHM are re-inerted if required. The MHM is repositioned over the MCO storage tube and floor valve.

NOTE: Prior to loading any fuel in the CSB, the MCO storage tubes shal1 have impact absorbers placed into the bottom of the tubes.

At the storage tube location, the MHM containing the MCO is positioned; the MHM isolation valve is opened; and the MCO is lowered into the MCO storage tube and finally disconnected from the MHM grapple. The grapple is withdrawn into the MHM; and the floor valve is closed. The MHM turret is rotated and the plug is lowered into the tube. The storage tube is immediately inerted and maintained slightly positively pressurized.

\subsection{STAGING}

Throughout the staging period with the MCOs vented to the tube environment, the tube atmosphere is monitored by periodic sampling and analysis, and controlled by venting and purging of inert gas as required to maintain the low pressure non-flammable gas in the tube/MCO environment.

The length of storage time for staging is dependent on the plan for conditioning of MCOs already staged versus MCOs just shipped from Cold Vacuum Orying, as the startup of the Hot Conditioning System lags the beginning of staging by approximately nine months. Assuming MCOs just processed through CVD are always given priority to Hot Conditioning over those in staging, and two years is required for Hot Conditioning of all $400 \mathrm{MCOS}$, then the last MCO taken from staging would have been stored approximately 2 years and nine months. 
WHC-SD-SNF-RPT-010, Revision 0

The maximum external wall temperature of an MCO with highest decay heat loading during staging is expected to be $132^{\circ} \mathrm{C}$; this is a design requirement of the CSB. The minimum external wall temperature of a minimum decay heat MCO may be rather close to the external environmental temperature; and thus may be as low as $-30^{\circ} \mathrm{C}$.

\subsection{HOT CONDITIONING SYSTEM}

The Hot Conditioning System PFD is depicted on $\mathrm{H}-2-825870$.

After short term staging the MCO is brought by the CSB MCO Handling Machine (MHM) to a conditioning station where the MCO is connected to the hot vacuum conditioning system. Hot conditioning will consist of heating the fuel to approximately $300^{\circ} \mathrm{C}$ under vacuum which will remove the chemically bound water and cause any uranium hydride to decompose and release hydrogen from the fuel. A passivation step may be added to the hot conditioning process following the hot vacuum step to reduce the overali reactivity of the fuel. In the passivation step the MCO would be cooled to $150^{\circ} \mathrm{C}$ and a controlled amount of oxygen added to the MCO to oxidize any remaining highly reactive surfaces.

Hot conditioning will proceed as follows: (1) MCO is received into the process cell by the CSB MHM; (2) MCO in process cell is connected to process gas piping, process off-gas piping, and process control systems; (3) vacuum system is started to initiate flow through the MCO; (4) inert gas is bied into MCO and vacuum pump continues to operate maintaining the purge flow; (5) heating is started and MCO core temperature is raised to $300^{\circ} \mathrm{C} ;(6)$ the $M C O$ pressure in the MCO is dropped to approximately 5 Torr, and the MCO remains at temperature for an estimated 48 hours; (7) heating is stopped at 48 hours and cooling begins; the MCO temperature is lowered to $150^{\circ} \mathrm{C} ;$ (8) A slight partial pressure of oxygen is introduced into the MCO in an inert carrier gas into the MCO to passivate any remaining highly reactive surfaces; (9) the partial pressure of oxygen is gradualiy raised; (10) The MC0 remains at $150^{\circ} \mathrm{C}$ with oxygen present for passivation for approximately 12 hours; (11) the MCO is allowed to cool to a temperature consistent with CSB acceptance criteria (assumed to be $132^{\circ} \mathrm{C}$ maximum); (12) the $\mathrm{MCO}$ is flushed with inert gas until no further oxygen is present in the MCO; (13) the MCO is isolated from the process and off-gas systems and then disconnected from the process and off-gas systems; (14) the MCO is seal welded if required; (15) the top of the MCO is surveyed and decontaminated as necessary; and (16) the MCO is removed from the process cell and placed in a long term storage location (40-75 Years) in a CSB storage tube by the CSB MHM.

Figure 5 summarizes the HCS processing times and temperatures. 


\subsection{INTERIM STORAGE}

Interim storage will occur within the CSB after MCOS are processed by the Hot Conditioning System and until they are shipped offsite to a permanent repository. This time period is expected to be 40 years but may be extended to 75 years. Temperatures during storage will be similar to those during staging but will decrease as decay heat decreases.

\subsection{UPSETS AND ACCIDENTS}

The objective of the MCO Pressurization Analysis is to provide a basis and capability to determine the internal pressure of an MCO under normal processing and storage conditions and expected off-normal conditions. Modeling of the internal pressure is to carried out for such conditions, as input to the final report, to determine at which points internal pressure or the significant gas constituents of hydrogen and oxygen reach levels of concern.

The worst case conditions for MCO pressurization will obviously be during off-normal events. These must be examined in addition to norma 1 processing sequences to fully evaluate the possible pressure histories of MCOs and defensibly evaluate sealed and vented processing options. The off-normal events within the scope of the MCO Pressurization Analysis are those affecting time, temperature, and/or reactions within the MCO to cause increase in internal pressure. Other events, such as those prior to welding or mechanically sealing the MCO or those with purely mechanical effects but no impact on time or temperature, are of interest to SNF Project in general but not to the Pressurization Analysis.

Analysis of design basis accidents will only be performed for events which fit the scope discussed in the preceding paragraph, such as design basis fires during transportation or within facilities. Consequences of off-normal events beyond temperature and pressure effects, such as particulate release or radiation dose, will not be examined as they are within the scope of safety Analysis Reviews (SARs).

The most significant parameters which would cause concern for process feasibility if reached during processing are:

- 150 psig internal pressure

- $>4 \%$ hydrogen

- >1-5 \% oxygen. 


\section{HOT CONDITIONING SYSTEM PROCESS TIME}

MCO core temperature is shown.

Nominal processing time is 122 hours.

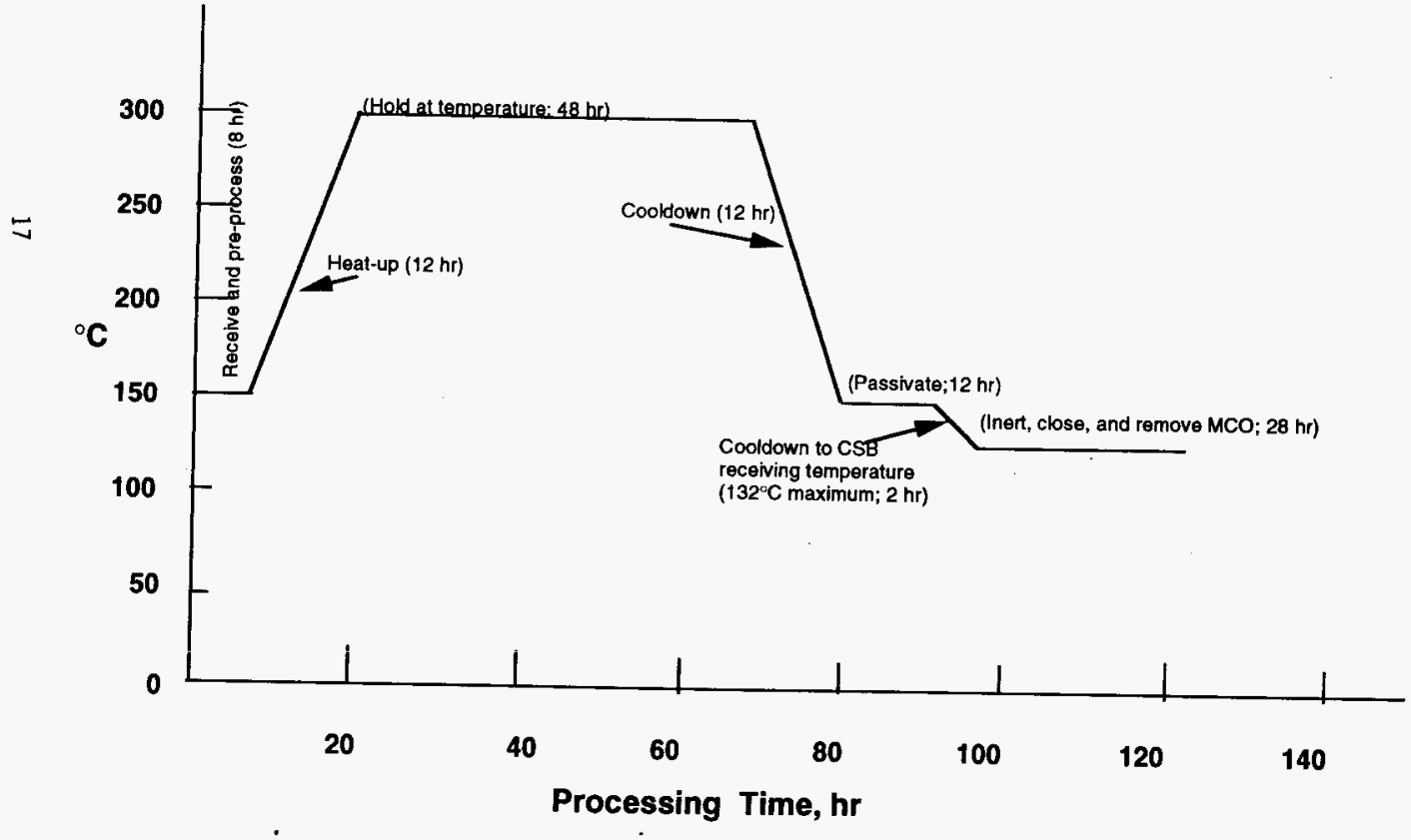


WHC-SD-SNF-RPT-010, Revision 0

Off-normal events within the MCO Pressurization Analysis scope are summarized below and in the table in the Appendix. The events were derived from a detajled assessment of possible MCO failure events in WHC-SD-SNF-RPT008 (to be released), which was based on Cold Vacuum Drying Facility and Canister Storage Building preliminary hazards analyses. Events are divided into upsets and accidents depending on relative severity of the event. The events are examples, based on engineering judgement, and are expected to change as subprojects proceed through final designs.

\subsection{TRANSFER FROM K BASINS TO THE COLD VACUUM DRYING FACILITY}

Upsets

- Administrative or equipment delays up to 12 hours

- Equipment faiTure resulting in stranding of Cask/MCO up to 7 days between facilities

\section{Accidents}

- MCO drop resulting in increase in fuel reactive surface area

- Design Basis Fire of $800^{\circ} \mathrm{C}$ for 30 minutes

\subsection{COLD VACUUM DRYING FACILITY}

\section{Upsets}

- Process connection blockage for up to 2 hours

- Administrative or equipment delays for up to 12 hours

\section{Accidents}

- Purge gas overpressure

- Water jacket overheating

- Incomplete draining of free water during Cold Vacuum Drying

\subsection{SHIPPING TO THE CANISTER STORAGE BUILDING}

Upsets

Administrative or equipment delays up to 12 hours 


$$
\text { WHC-SD-SNF-RPT-010, Revision } 0
$$

\section{Accidents}

- Equipment failure resulting in stranding of Cask/MCO up to 7 days between facilities

- MCO drop resulting in increase in fuel reactive surface area

- Incomplete draining of free water during Cold Vacuum Drying

\subsection{STAGING AT THE CANISTER STORAGE BUILDING}

Upsets

- Administrative or equipment delays up to 12 hours

- MCO vent connection blockage for up to 2 hour

\section{Accidents}

- MCO vent connection blockage

- Building ventilation flow blockage of $50 \%$

- MCO drop resulting in increase in fuel reactive surface area

- Incomplete draining of free water during cold Vacuum Drying

\subsection{HOT CONDITIONING SYSTEM}

\section{Upsets}

- Administrative or equipment delays up to 12 hours

- MCO process connection blockage for up to 2 hours

\section{Accidents}

- Process gas overpressure

- Wrong gas mixture $\left(100 \% 0_{2}\right)$

- Incomplete draining of free water during Cold Vacuum Drying

- System overheating 


$$
\text { WHC-SD-SNF-RPT-010, Revision } 0
$$

\subsection{INTERIM STORAGE AT THE CANISTER STORAGE BUILDING}

Upsets

- Administrative or equipment delays up to 12 hours

- MCO process connection blockage for up to 2 hours

\section{Accidents}

- Vault ventilation flow blockage of $50 \%$

- MCO drop resulting in increase in fuel reactive surface area

- Excess bound water inventory 


$$
\text { WHC-SD-SNF-RPT-010, Revision } 0
$$

\section{APPENDIX A}

Process steps and durations are presented, along with expected effects of upset events on process step durations. 


\section{OPERATIONS DESCRIPTION}

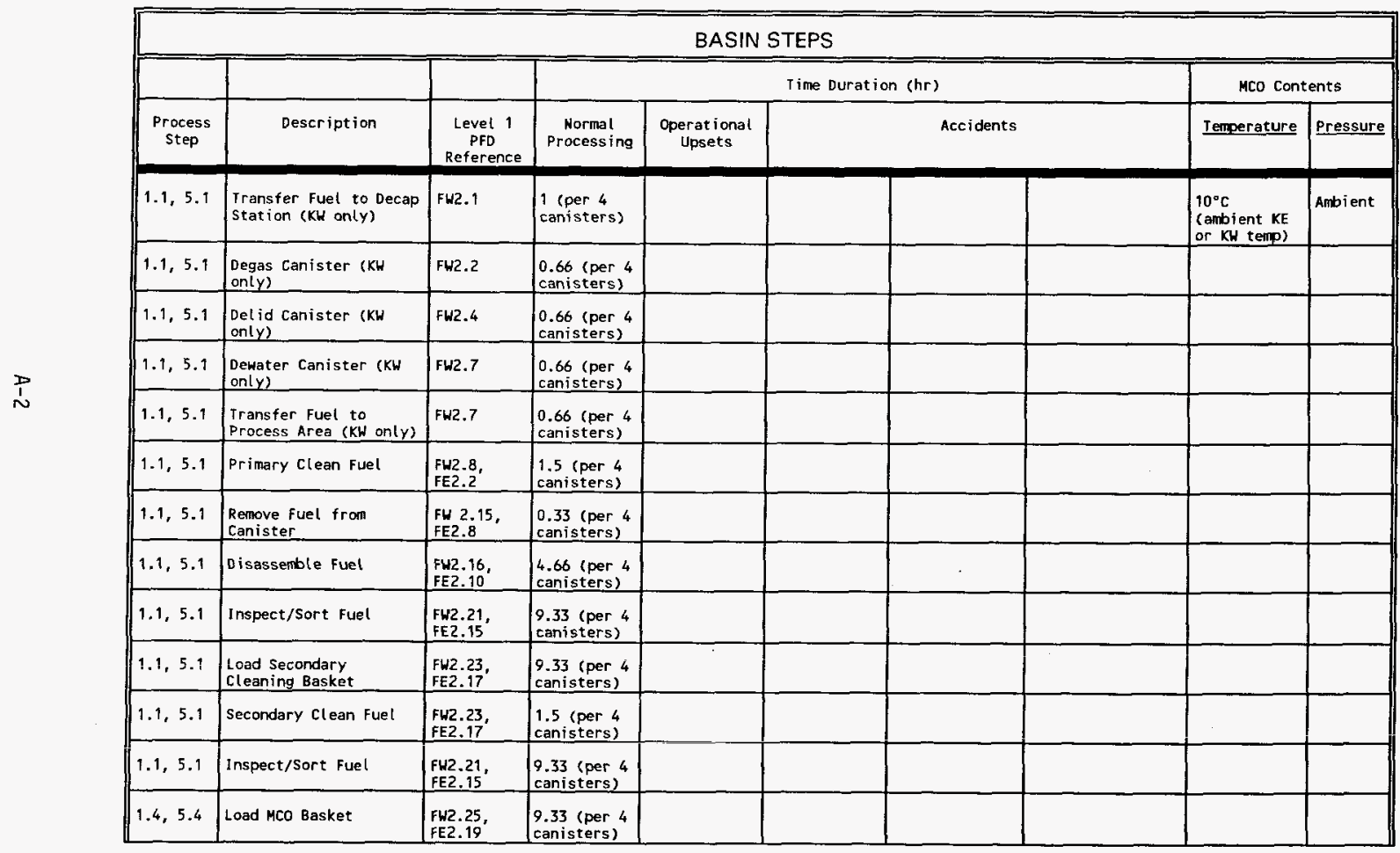




\section{OPERATIONS DESCRIPTION}

\begin{tabular}{|c|c|c|c|c|c|c|c|c|}
\hline \multicolumn{9}{|c|}{ BASIN STEPS } \\
\hline \multirow[b]{2}{*}{$\begin{array}{l}\text { Process } \\
\text { Step }\end{array}$} & \multirow[b]{2}{*}{ Description } & \multirow[b]{2}{*}{$\begin{array}{c}\text { Level } 1 \\
\text { PFD } \\
\text { Reference }\end{array}$} & \multicolumn{4}{|c|}{ Time Duration (hr) } & \multicolumn{2}{|c|}{ MCO Contents } \\
\hline & & & $\begin{array}{c}\text { Mormal } \\
\text { Process ing }\end{array}$ & $\begin{array}{l}\text { Operational } \\
\text { Upsets }\end{array}$ & & Accidents & temperature & Pressure \\
\hline $1.4,5.4$ & Stage MCO Basket & $\begin{array}{l}\text { FW2.27, } \\
\text { FE2.21 }\end{array}$ & $\begin{array}{l}0.28 \text { (per } 4 \\
\text { canisters) } \\
\end{array}$ & & & & & \\
\hline $2.9,6.9$ & $\begin{array}{l}\text { Load MCO--Load MCO } \\
\text { with Baskets in KE }\end{array}$ & $\begin{array}{l}\text { FE2.22, } \\
\text { FW2.28 }\end{array}$ & 4 & & & & $\begin{array}{l}10^{\circ} \mathrm{c} \\
\text { (ambi ent } \mathrm{K} \\
\text { East or } \mathrm{K} \\
\text { West Basin } \\
\text { temperature) }\end{array}$ & \\
\hline & & & & & & & $\begin{array}{l}10^{\circ} \mathrm{C} \\
\text { (ambient } \mathrm{K} \\
\text { East or } \mathrm{K} \\
\text { West Basin } \\
\text { temperature) }\end{array}$ & \\
\hline $3.4-3.8$ & $\begin{array}{l}\text { Survey, dry cask, } \\
\text { attach to transport, } \\
\text { complete survey, } \\
\text { fasten cask Lid (KE) }\end{array}$ & $\begin{array}{l}\text { TE1.2 } \\
\text { TE1.3 } \\
\text { TE2.4 }\end{array}$ & 4.75 & & & & & \\
\hline $7.4-7.8$ & $\begin{array}{l}\text { Survey, dry cask, } \\
\text { attach to transport, } \\
\text { complete survey, } \\
\text { fasten cask (id (KW) }\end{array}$ & $\begin{array}{l}\text { IH1.2 } \\
\text { IW1.3 } \\
\text { TH2.4 }\end{array}$ & 4.75 & & & & & \\
\hline $9.1 b-9.2$ & $\begin{array}{l}\text { Secure MCO/Cask } \\
\text { Iransporter to VDM- } \\
\text { Verifp toperability of } \\
\text { conf inement system, } \\
\text { drive transporter into } \\
\text { and out of processing } \\
\text { station }\end{array}$ & v1.1 & 1.4 & & $\begin{array}{l}\text { Iransport } \\
\text { Accident-- } \\
\text { single event } \\
\text { probability } \\
\text {-E-3; normal } \\
\text { processing } \\
\text { plus } 1 \text { week } \\
\end{array}$ & & & \\
\hline
\end{tabular}


OPERATIONS DESCRIPTION

\begin{tabular}{|c|c|c|c|c|c|c|c|c|c|}
\hline \multicolumn{10}{|c|}{ COLD VACUUM DRYING STEPS } \\
\hline \multirow[b]{2}{*}{$\begin{array}{l}\text { Pracess } \\
\text { Step }\end{array}$} & \multirow[b]{2}{*}{ Description } & \multirow[b]{2}{*}{$\begin{array}{c}\text { Level } \\
\text { PFD } \\
\text { Reference }\end{array}$} & \multicolumn{5}{|c|}{ Time Duration $(\mathrm{hr})$} & \multicolumn{2}{|c|}{ MCO Contents } \\
\hline & & & $\begin{array}{c}\text { Normal } \\
\text { Processing }\end{array}$ & $\begin{array}{l}\text { Operational } \\
\text { Upsets }\end{array}$ & & Accidents & & Iemperature & Pressure \\
\hline 3.11 & $\begin{array}{l}\text { Ship to CVO (KE) } \\
\text { (Cask/MCO at basin) }\end{array}$ & TE3.1 & 2 & $\begin{array}{l}\text { Adninistrative/ } \\
\text { mechanical } \\
\text { delay (up to } 12 \\
\text { hr delay in } \\
\text { shipping) } \\
(-E-3)\end{array}$ & $\begin{array}{l}\text { Drop Accident - - } \\
\text { single event } \\
\text { probability } \\
- \text { - } 5 \text {; normal } \\
\text { processing plus } \\
1 \text { week }\end{array}$ & & $\begin{array}{l}\text { Iransport delay: } \\
\text { e.g- weather } \\
\text { mechanical } \\
\text { breakdown, etc.-- } \\
\text { single event } \\
\text { probabil lity -E-3; } \\
\text { normal processing } \\
\text { plus } 1 \text { week }\end{array}$ & & \\
\hline 3.11 & $\begin{array}{l}\text { Ship to CVD (KE) } \\
\text { (Cask/MCo between } \\
\text { facilities) }\end{array}$ & TE3.9 & 2 & \begin{tabular}{|l} 
Acministrative/ \\
mechanical \\
delay (up to 12 \\
hr time in \\
transit) (-E-3)
\end{tabular} & $\begin{array}{l}\text { Transportation } \\
\text { Breakdown--up } \\
\text { to } 1 \text { week } \\
\text { delay, ambient } \\
\text { Hanford } \\
\text { temperature }) \\
(\sim E-3) \\
\end{array}$ & $\begin{array}{l}\text { Design Basis } \\
\text { Fire-during } \\
\text { transportation } \\
(30 \text { minutes at } \\
\left.800^{\circ} \mathrm{C}\right)\end{array}$ & & & \\
\hline 7.11 & $\begin{array}{l}\text { Ship to CVD (KW) } \\
\text { (Cask/MCO at basin) }\end{array}$ & TW3.1 & 2 & $\begin{array}{l}\text { Administrative/ } \\
\text { mechanical } \\
\text { delay (up to } 12 \\
\text { hr delay in } \\
\text { shipping) } \\
(\sim-3-3)\end{array}$ & $\begin{array}{l}\text { Drop Accident- } \\
\text { single event } \\
\text { probabil ity } \\
- \text { E-3; normal } \\
\text { processing plus } \\
1 \text { week }\end{array}$ & & $\begin{array}{l}\text { Iransport delay: } \\
\text { e.g. Heather. } \\
\text { mechanical } \\
\text { breakdown, etc.-- } \\
\text { single event } \\
\text { probabi l ity -E-3; } \\
\text { normal processing } \\
\text { plus } 1 \text { week }\end{array}$ & & \\
\hline 7.11 & $\begin{array}{l}\text { Ship to CVD (KW) } \\
\text { (Cask/MCO between } \\
\text { facilities) }\end{array}$ & TW3.1 & 2 & $\begin{array}{l}\text { Adninistrativer } \\
\text { mechanical } \\
\text { delay (up to 12 } \\
\text { hr time in } \\
\text { transit) (-E-3) }\end{array}$ & $\begin{array}{l}\text { Transportation } \\
\text { Breakdown- - up } \\
\text { to } 1 \text { week } \\
\text { delay, ambient } \\
\text { Hanford } \\
\text { temperature }) \\
(-E-3) \\
\end{array}$ & & & & \\
\hline $\begin{array}{l}2.9 a-3.3 \\
6.9 a-7.4\end{array}$ & $\begin{array}{l}\text { Weld MCO lid and } \\
\text { inspect--Fer form ai } i \\
\text { MCo and cask movements } \\
\text { and operations to weld } \\
\text { Mco lid and inspect } \\
\text { weld }\end{array}$ & $\begin{array}{l}\text { ME } 2.4 \\
\text { MEE } 2.5\end{array}$ & $\begin{array}{l}21.87 \\
(T A-008) \\
13.9 \\
(R P T-002)\end{array}$ & & & & & $\begin{array}{l}20^{\circ} \mathrm{c} \\
\text { (ambient } \\
\text { cVD) }\end{array}$ & 7 tóv torr \\
\hline
\end{tabular}


OPERATIONS DESCRIPTION

COLD VACUUM DRYING STEPS

\begin{tabular}{|c|c|c|c|c|c|c|c|c|c|}
\hline \multicolumn{10}{|c|}{ COLD VACUUM DRYING STEPS } \\
\hline \multirow[b]{2}{*}{$\begin{array}{l}\text { Process } \\
\text { Step }\end{array}$} & \multirow[b]{2}{*}{ Description } & \multirow[b]{2}{*}{$\begin{array}{c}\text { Level } 1 \\
\text { PFD } \\
\text { Reference }\end{array}$} & \multicolumn{5}{|c|}{ Time Duration (hr) } & \multicolumn{2}{|c|}{ Mco Contents } \\
\hline & & & $\begin{array}{c}\text { Normal } \\
\text { Processing }\end{array}$ & $\begin{array}{l}\text { Operational } \\
\text { Upsets }\end{array}$ & \multicolumn{3}{|c|}{ Accidents } & Temperature & Pressure \\
\hline $\mid \begin{array}{l}9.4 \\
9.5 \\
9.5 a\end{array}$ & $\begin{array}{l}\text { Pre-Process Steps-- } \\
\text { Connect and initiate } \\
\text { cool ing system, } \\
\text { connect process lines, } \\
\text { sample, vent, and } \\
\text { purge }\end{array}$ & V1.1 & 2 & $\begin{array}{l}\text { Connector } \\
\text { Failure (leak } \\
\text { or blockage) } \\
\text { single event } \\
\text { probabil ity } \\
\text { E }+0 \text {; normal } \\
\text { processing plus } \\
2 \text { hours } \\
\end{array}$ & & & & & \\
\hline $\begin{array}{l}9.8 \\
9.6 \\
9.9\end{array}$ & $\begin{array}{l}\text { Process steps }-. \\
\text { Initiate heatup to } \\
50^{\circ} \mathrm{C} \text { at } 20^{\circ} \mathrm{C} / \mathrm{hr} \text {, drain } \\
\text { bulk water, purge with } \\
\text { inert gas, achieve } \\
\text { final vacum, hold for } \\
13 \mathrm{hr} \text {, ramp to } 75^{\circ} \mathrm{C} \text { at } \\
2.5^{\circ} \mathrm{C} / \mathrm{hr}, \mathrm{cool} \text { down to } \\
25^{\circ} \mathrm{C} \text { at } 10^{\circ} \mathrm{C} / \mathrm{hr}\end{array}$ & $\begin{array}{l}v 1.2 \\
v 1.3 \\
v 1.4\end{array}$ & 31.8 & $\begin{array}{l}\text { Connector } \\
\text { Failure (leak } \\
\text { or blockage)- } \\
\text { singte event } \\
\text { probabil ity } \\
\text {-E+0; normal } \\
\text { processing plus } \\
2 \text { hours }\end{array}$ & $\begin{array}{l}\text { Gas } \\
\text { overpressure }\end{array}$ & $\begin{array}{l}\text { Water jacket } \\
\text { overheat ing }\end{array}$ & $\begin{array}{l}\text { Incomplete draining } \\
\text { of free water }\end{array}$ & $\begin{array}{l}\text { Ramp to } 50^{\circ} \mathrm{C} \\
\text { and hold, } \\
\text { ramp to } \\
75^{\circ} \mathrm{C} \text {, cool } \\
\text { to } 25^{\circ} \mathrm{C}\end{array}$ & \\
\hline $9.10-9.14$ & $\begin{array}{l}\text { Inert and Disconnect } \\
\text { and decon, disconnect } \\
\text { and seal, remove } \\
\text { process hood from } \\
\text { cask, install cask } \\
\text { cover, survey and } \\
\text { decontaminate, hel ium } \\
\text { check cask seals }\end{array}$ & v1.5 & 3.3 & $\begin{array}{l}\text { Connector } \\
\text { Failure (leak } \\
\text { or blockage) } \\
\text { single event } \\
\text { probabil ity } \\
\sim \text { E+0; normal } \\
\text { processing plus } \\
2 \text { hours }\end{array}$ & & & & & \\
\hline $9.16-9.18$ & $\begin{array}{l}\text { Remove MCo/Cask from } \\
\text { VDM--Remove } \\
\text { cask/transport } \\
\text { restraints, } \\
\text { survey/decon for } \\
\text { shipment } \\
\end{array}$ & $\begin{array}{l}13.2 .1 \\
13.2 .2\end{array}$ & 4.3 & & & & & & \\
\hline
\end{tabular}




\section{OPERATIONS DESCRIPTION}

\begin{tabular}{|c|c|c|c|c|c|c|c|c|c|}
\hline \multicolumn{10}{|c|}{ COLD VACUUM DRYING STEPS } \\
\hline \multirow[b]{2}{*}{$\begin{array}{l}\text { Process } \\
\text { Step }\end{array}$} & \multirow[b]{2}{*}{ Deseription } & \multirow[b]{2}{*}{$\begin{array}{c}\text { Level } 1 \\
\text { PFD } \\
\text { Reference }\end{array}$} & \multicolumn{5}{|c|}{ Time Duration $(h r)$} & \multicolumn{2}{|c|}{ MCO Contents } \\
\hline & & & $\begin{array}{c}\text { Normal } \\
\text { Processing }\end{array}$ & $\begin{array}{l}\text { Operational } \\
\text { Upsets }\end{array}$ & & Accidents & & Temperature & Pressure \\
\hline 9.19 & $\frac{\text { Ship Cask to CSB }}{\text { (Cask/MCO at CVD) }}$ & 13.2 .3 & 4 & $\begin{array}{l}\text { Administrativef } \\
\text { mechanical } \\
\text { delay (up to } 8 \\
\text { hr delay in } \\
\text { shipping) } \\
(- \text { - }-3)\end{array}$ & $\begin{array}{l}\text { Excess water } \\
\text { remaining after } \\
\text { cvo (2x, 5x } \\
\text { expected } \\
\text { amount) }\end{array}$ & & & $\begin{array}{l}20^{\circ} \mathrm{C} \\
\text { (ambient) }\end{array}$ & $\begin{array}{l}900 \text { torr } \\
\text { exiting } \\
\text { cvo }\end{array}$ \\
\hline 9.19 & $\begin{array}{l}\frac{\text { Ship to CSB }}{\text { (Cask/HCo between }} \\
\text { facilities) }\end{array}$ & $\mathrm{T} 3.2 .3$ & 4 & $\begin{array}{l}\text { Adninistrative/ } \\
\text { mechanical } \\
\text { delay (up to } 8 \\
\text { hr delay time } \\
\text { in transmit) } \\
(\sim E-3)\end{array}$ & $\begin{array}{l}\text { Excess water } \\
\text { remaining after } \\
\text { cvo }(2 x, 5 x \\
\text { expected } \\
\text { amount) }\end{array}$ & $\begin{array}{l}\text { Iransportation } \\
\text { Breakdown-- (up } \\
\text { to } 1 \text { week } \\
\text { delay, ambient } \\
\text { Hanford } \\
\text { t moperature) } \\
(- \text { E-3) }\end{array}$ & $\begin{array}{l}\text { Design Bas is Fire-- } \\
\text { during } \\
\text { transportation }(30 \\
\left.\text { minutes at } 800^{\circ} \mathrm{C}\right)\end{array}$ & & \\
\hline
\end{tabular}




\section{OPERATIONS DESCRIPTION}

\begin{tabular}{|c|c|c|c|c|c|c|c|c|}
\hline \multicolumn{9}{|c|}{ STAGING STEPS } \\
\hline \multirow[b]{2}{*}{$\begin{array}{l}\text { Process } \\
\text { Step }\end{array}$} & \multirow[b]{2}{*}{ Description } & \multirow[b]{2}{*}{$\begin{array}{c}\text { Level } 1 \\
\text { PFD } \\
\text { Reference }\end{array}$} & \multicolumn{4}{|c|}{ Time Duration (hr) } & \multicolumn{2}{|c|}{ MCO Contents } \\
\hline & & & $\begin{array}{c}\text { Normal } \\
\text { Processing }\end{array}$ & $\begin{array}{l}\text { Operat ional } \\
\text { Upsets }\end{array}$ & . & Accidents & Iemperature & Pressure \\
\hline 10.1 & $\begin{array}{l}\text { Move transport into } \\
\text { CSB }\end{array}$ & c1.3 & 0.5 & $\begin{array}{l}\text { Administrative/ } \\
\text { mechanicat } \\
\text { delay (up to } 12 \\
\text { hrs) }(-E-3)\end{array}$ & & $\begin{array}{l}\text { Transport } \\
\text { accident--up } \\
\text { to } 1 \text { week } \\
\text { delay, ambient } \\
\text { Hanford } \\
\text { temperature } \\
\text { (-E-3) }\end{array}$ & & \\
\hline 10.2 & Position lifting yoke & c1.3 & 0.25 & & & & & \\
\hline 10.3 & $\begin{array}{l}\text { Remove impact } \\
\text { absorbers }\end{array}$ & $c 1.3$ & 0.5 & & & & & \\
\hline 10.4 & Lift yoke & $c 1.3$ & 0.25 & & & & & \\
\hline 10.5 & Remove cask tiedowns & $c 9.3$ & 0.5 & & & & & \\
\hline 10.6 & $\begin{array}{l}\text { Move cask to pit and } \\
\text { tower }\end{array}$ & c1.3 & 0.25 & & $\begin{array}{l}\text { Drop } \\
\text { accident-- } \\
\text { single event } \\
\text { probability } \\
-E-5 ; \text {; normal } \\
\text { processing } \\
\text { plus 2 weeks }\end{array}$ & $\begin{array}{l}\text { Drop accident- } \\
\text {-up to } 2 \text { weeks } \\
\text { delay, ambient } \\
\text { CSB } \\
\text { temperature }) \\
(-E-5)\end{array}$ & & \\
\hline 10.7 & $\begin{array}{l}\text { Place yoke on floor or } \\
\text { stand }\end{array}$ & c1.3 & 0.25 & & & & & \\
\hline 10.8 & $\begin{array}{l}\text { Place enclosure over } \\
\text { pit }\end{array}$ & $\mathrm{cl} .3$ & 1 & & & & & \\
\hline 10.9 & Saniple air inside cask & $c 1.4$ & 0.5 & & & & & \\
\hline 10.10 & Remove cask ! id & 61.4 & 0.5 & & & & & \\
\hline 10.11 & Install shielding ring & c1.4 & 0.25 & & & & & \\
\hline 10.12 & Check rupture disk & C1.4 & 0.25 & & & & & \\
\hline
\end{tabular}




\section{OPERATIONS DESCRIPTION}

\begin{tabular}{|c|c|c|c|c|c|c|c|c|}
\hline \multicolumn{9}{|c|}{ STAGING STEPS } \\
\hline \multirow[b]{2}{*}{$\begin{array}{c}\text { Process } \\
\text { Step }\end{array}$} & \multirow[b]{2}{*}{ Description } & \multirow[b]{2}{*}{$\begin{array}{c}\text { Level } 1 \\
\text { PFD } \\
\text { Reference }\end{array}$} & \multicolumn{4}{|c|}{ Tinse Duration (hr) } & \multicolumn{2}{|c|}{ MCO Contents } \\
\hline & & & $\begin{array}{l}\text { Normat } \\
\text { Processing }\end{array}$ & $\begin{array}{l}\text { Operational } \\
\text { Upsets }\end{array}$ & & Accidents & Iemperature & Pressure \\
\hline 10.13 & $\begin{array}{l}\text { Install venting } \\
\text { package }\end{array}$ & $c 1.5$ & 0.25 & $\begin{array}{l}\text { Connector } \\
\text { failure (leak } \\
\text { or blockage) } \\
\text { single event } \\
\text { probability } \\
\text { - } \mathrm{E}+0 \text {; normal } \\
\text { processing plus } \\
2 \text { hours } \\
\end{array}$ & & & & \\
\hline 10.14 & Vent \& purge MCO & c1.5 & 1.5 & $\begin{array}{l}\text { Connect or } \\
\text { failure fleak } \\
\text { or blackage) } \\
\text { single event } \\
\text { probability } \\
- \text { E+0; normal } \\
\text { processing plus } \\
2 \text { hours } \\
\end{array}$ & & & & \\
\hline 10.15 & Remove shielding ring & C1.6 & 0.25 & & & & & \\
\hline 10.16 & Decon/survey & $c 1.6$ & 0.5 & & & & & \\
\hline 10.17 & Remove enclosure pit & $c 1.6$ & 0.5 & & & & & \\
\hline 10.18 & $\begin{array}{l}\text { Place interface ring } \\
\text { over pit }\end{array}$ & c1.6 & 0.25 & & & & & \\
\hline 10.19 & Place MCO into MHM & c1.6 & 0.25 & & $\begin{array}{l}\text { Drop } \\
\text { accident-- } \\
\text { single event } \\
\text { probability } \\
\text { E-5; normal } \\
\text { processing } \\
\text { plus 2 weaks } \\
\end{array}$ & & & \\
\hline 10.20 & Inert MHM & c1.6 & 0.17 & & & & & \\
\hline 10.21 & $\begin{array}{l}\text { Remove interface ring } \\
\text { from pit }\end{array}$ & c1.6 & 0.25 & & & & & \\
\hline
\end{tabular}




\section{OPERATIONS DESCRIPTION}

\begin{tabular}{|c|c|c|c|c|c|c|c|c|c|}
\hline \multicolumn{10}{|c|}{ STAGING STEPS } \\
\hline \multirow[b]{2}{*}{$\begin{array}{l}\text { Process } \\
\text { Step }\end{array}$} & \multirow[b]{2}{*}{ Description } & \multirow[b]{2}{*}{$\begin{array}{c}\text { Level } 1 \\
\text { PFD } \\
\text { Reference }\end{array}$} & \multicolumn{5}{|c|}{ Time Duration $(\mathrm{hr})$} & \multicolumn{2}{|c|}{ MCO Contents } \\
\hline & & & $\begin{array}{c}\text { Normal } \\
\text { Processing }\end{array}$ & $\begin{array}{l}\text { Operat ional } \\
\text { Upsets }\end{array}$ & \multicolumn{3}{|c|}{ Accidents } & Iemperature & Pressure \\
\hline 10.22 & Move MHM over tube & c1.6 & 0.17 & & & & & & \\
\hline 10.23 & $\begin{array}{l}\text { Lift plug into мНM } \\
\text { turret }\end{array}$ & c1.6 & 0.17 & & & & & & \\
\hline 10.24 & Rotate Mнм turret & c1.6 & 0.17 & & & & & & \\
\hline 10.25 & Inert tube & c1.6 & 0.17 & & & & & & \\
\hline 10.26 & Place $\mathrm{MCO}$ in tube & $\mathrm{c} 2.2$ & 0.5 & & $\begin{array}{l}\text { Drop } \\
\text { accident-- } \\
\text { scingle event } \\
\text { probability } \\
\text {-E-5; normal } \\
\text { processing } \\
\text { plus 2 weeks }\end{array}$ & & & & \\
\hline 10.27 & Rotate turret & $c 2.2$ & 0.17 & & & & & & \\
\hline 10.28 & Install plug & $\mathrm{c} 2.2$ & 0.25 & & & & & & \\
\hline \multirow[t]{2}{*}{10.29} & Verify monitoring & $c 2.4$ & 0.17 & & & & & & \\
\hline & staging period & $\mathrm{c} 2.4$ & $\operatorname{lup}_{-2-3 / 4}$ to $\mathrm{yr}$ & & $\begin{array}{l}\text { Excess water } \\
\text { remaining } \\
\text { after cVo } \\
\text { (2x, } 5 x \\
\text { expected } \\
\text { ameunt) } \\
\end{array}$ & $\begin{array}{l}\text { Loss of } 50 \\
100 \% \text { of inlet } \\
\text { plenum area } \\
\text { for } 1 \text { week } \\
\text { (ambi ent cSB } \\
\text { temperature) }\end{array}$ & $\begin{array}{l}\text { Mco vent blockage } \\
\text { up to } 7 \text { days }\end{array}$ & $\begin{array}{l}132^{\circ} \mathrm{C} \\
\text { maximum } \\
\text { external MCO } \\
\text { walt } \\
\text { temperature }\end{array}$ & 760 torr \\
\hline
\end{tabular}




\section{OPERATIONS DESCRIPTION}

\begin{tabular}{|c|c|c|c|c|c|c|c|c|}
\hline \multicolumn{9}{|c|}{ HOT CONDITIONING SYSTEM } \\
\hline \multirow[b]{2}{*}{$\begin{array}{l}\text { Process } \\
\text { Step }\end{array}$} & \multirow[b]{2}{*}{ Description } & \multirow[b]{2}{*}{$\begin{array}{c}\text { Level } 1 \\
\text { PFD } \\
\text { Reference }\end{array}$} & \multicolumn{4}{|c|}{ Time Duration (hr) } & \multicolumn{2}{|c|}{ MCO Contents } \\
\hline & & & $\begin{array}{c}\text { Normal } \\
\text { Processing }\end{array}$ & $\begin{array}{l}\text { Operat ional } \\
\text { Upsets }\end{array}$ & & Accidents & Iemperature & Pressure \\
\hline 12.1 & Move MHM to tube & c2.5 & 0.5 & & $\begin{array}{l}\text { Drop } \\
\text { accident-- } \\
\text { single event } \\
\text { probability } \\
\text {-E-5; normal } \\
\text { processing } \\
\text { plus 2 weeks }\end{array}$ & & & \\
\hline 12.2 & Survey area & $\mathrm{C} 2.5$ & 0.5 & & & & & \\
\hline 12.3 & Remove cover plate & $\mathrm{C} 2.5$ & 0.25 & & & & & \\
\hline 12.4 & Move MHM over tube & C2.5 & 0.17 & & & & & \\
\hline 12.5 & $\begin{array}{l}\text { Lift plug into MHM } \\
\text { turret }\end{array}$ & C. 25 & 0.25 & & & & & \\
\hline 12.6 & Rotate MHM turret & $\mathrm{c} 2.5$ & 0.17 & & & & & \\
\hline 12.7 & Place MCo into MHм & $\mathrm{c} 2.5$ & 0.25 & & $\begin{array}{l}\text { Drop } \\
\text { accident-- } \\
\text { single event } \\
\text { probability } \\
\text {-E-5; normal } \\
\text { processing } \\
\text { plus 2 weeks } \\
\end{array}$ & & & \\
\hline 12.8 & Move MHM to HCS & P1.1 & 0.17 & & $\begin{array}{l}\text { Drop } \\
\text { accident-- } \\
\text { single event } \\
\text { probabil i ty } \\
\text { - E-5; normal } \\
\text { processing } \\
\text { plus } 2 \text { weeks } \\
\end{array}$ & & & \\
\hline 12.9 & Remove CSB floor valve & $P 1.1$ & 0.17 & & 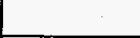 & & & \\
\hline
\end{tabular}




\section{OPERATIONS DESCRIPTION}

\begin{tabular}{|c|c|c|c|c|c|c|c|c|}
\hline \multicolumn{9}{|c|}{ HOT CONDITIONING SYSTEM } \\
\hline \multirow[b]{2}{*}{$\begin{array}{l}\text { Process } \\
\text { Step }\end{array}$} & \multirow[b]{2}{*}{ Description } & \multirow[b]{2}{*}{$\begin{array}{c}\text { Level } 1 \\
\text { PFD } \\
\text { Reference }\end{array}$} & \multicolumn{4}{|c|}{ rime Duration (hr) } & \multicolumn{2}{|c|}{ MCO Contents } \\
\hline & & & $\begin{array}{c}\text { Normal } \\
\text { Processing }\end{array}$ & $\begin{array}{l}\text { Operational } \\
\text { Upsets }\end{array}$ & & Accidents & Temperature & Pressure \\
\hline 12.11 & Survey/decon & P1.1 & 0.5 & & & & & \\
\hline $14.1-14.8$ & $\begin{array}{l}\text { Receive into process } \\
\frac{\text { area-- Survey, place }}{\text { MCO into process pit }}\end{array}$ & P1.2 & 4 & & $\begin{array}{l}\text { Drop } \\
\text { accident.-. } \\
\text { single event } \\
\text { probability } \\
\text {-E-5; normal } \\
\text { processing } \\
\text { plus 2 weeks } \\
\end{array}$ & & & \\
\hline $14 . x$ & $\begin{array}{l}\text { Cool from staging } \\
\text { temperature }\end{array}$ & P2.1 & 8 & & & & & \\
\hline $\begin{array}{l}14.9- \\
14.12\end{array}$ & $\begin{array}{l}\text { Connect to gas/vacuum } \\
\text { system- - Commect gasf } \\
\text { vacuin lines, seal } \\
\text { HEPA \& rupture disk } \\
\text { ports, remove vent } \\
\text { hood, install top to } \\
\text { process pit }\end{array}$ & P2.1 & 4 & $\begin{array}{l}\text { Connector } \\
\text { failure (leak } \\
\text { or blockage) } \\
\text { single event } \\
\text { probabi it ty } \\
\text { - E+0; ; nornal } \\
\text { processing } \\
\text { plus } 2 \text { hours }\end{array}$ & & & & \\
\hline 14.13 & $\begin{array}{l}\text { Heat-up- }- \text { MCO is heated } \\
\text { from ambient }\left(-40^{\circ} \mathrm{C}\right) \\
\text { to } 300^{\circ} \mathrm{C} \text { at }-20^{\circ} \mathrm{C} / \mathrm{hr}\end{array}$ & P2.1 & 12 & & $\begin{array}{l}\text { Heating } \\
\text { system } \\
\text { runaway to } \\
450^{\circ} \mathrm{C}\end{array}$ & $\begin{array}{l}\text { Hrong } \\
\text { pass ivat ion } \\
\text { gas mix }(100 \% \\
\mathrm{O}_{2} \text { rather than } \\
\left.2 \mathrm{O}_{2}\right) \\
\end{array}$ & $3^{\text {Ramp }}$ to & \\
\hline 14.13 & $\begin{array}{l}\text { Conditioning- } \\
\text { pressure is reduced to } \\
-1 \text { torr and } \mathrm{MCO} \text { is } \\
\text { held for } 48 \mathrm{hr} \\
\end{array}$ & P2.1 & 48 & & & & & \\
\hline 14.13 & $\begin{array}{l}\text { Cool ing to passivation } \\
\text { temperature- } \\
\text { Temperature is lowered } \\
\text { to } 150^{\circ} \mathrm{C} \text { at }-12^{\circ} \mathrm{C} / \mathrm{hr}\end{array}$ & P2.1 & 12 & & & & & \\
\hline
\end{tabular}




\section{OPERATIONS DESCRIPTION}

\begin{tabular}{|c|c|c|c|c|c|c|c|c|}
\hline \multicolumn{9}{|c|}{ HOT CONDITIONING SYSTEM } \\
\hline \multirow[b]{2}{*}{$\begin{array}{l}\text { Process } \\
\text { Step }\end{array}$} & \multirow[b]{2}{*}{ Description } & \multirow[b]{2}{*}{$\begin{array}{c}\text { Level } 1 \\
\text { PFD } \\
\text { Reference }\end{array}$} & \multicolumn{4}{|c|}{ Time Duration (hr) } & \multicolumn{2}{|c|}{ MCO Contents } \\
\hline & & & $\begin{array}{c}\text { Normal } \\
\text { Processing }\end{array}$ & $\begin{array}{l}\text { Operational } \\
\text { Upsets }\end{array}$ & & Accidents & Iemperature & Pressure \\
\hline 14.13 & $\begin{array}{l}\text { Passivation--slight } \\
\text { partial pressure of } \\
\text { oxygen is bled into } \\
\text { mco }\end{array}$ & P3.1 & 12 & & & & & \\
\hline 14.14 & $\begin{array}{l}\text { Cooldown from } \\
\text { passivation } \\
\text { fram } 150^{\circ} \mathrm{C} \text { - } \\
\text { fo cooldown } \\
\text { acceptance temperature } \\
\text { of } 132^{\circ} \mathrm{C} \text { C } \\
\end{array}$ & P3.1 & 10 & & & & $\begin{array}{l}132^{\circ} \mathrm{C} \\
\text { maximum } \\
\text { exiting HCS }\end{array}$ & \\
\hline $\begin{array}{l}14.15- \\
14.26\end{array}$ & $\begin{array}{l}\text { Inert and closure-- } \\
\text { Plush with inert gas, } \\
\text { disconnect supply } \\
\text { lines, seal Mco } \\
\text { openings, inspect seal } \\
\text { welds }\end{array}$ & $\begin{array}{l}\text { P8.1 } \\
\text { P8.2 } \\
\text { P8.3 } \\
\text { P8.4 } \\
\text { P8.5 }\end{array}$ & 24 & & $\begin{array}{l}\text { Connector } \\
\text { fai lure (leak } \\
\text { or blockage) } \\
\text {-single event } \\
\text { probability } \\
\text {-E+0; normal } \\
\text { processing } \\
\text { plus 2 hours } \\
\end{array}$ & & & \\
\hline
\end{tabular}




\section{OPERATIONS DESCRIPTION}

\begin{tabular}{|c|c|c|c|c|c|c|c|}
\hline \multicolumn{8}{|c|}{ MOVE TO STORAGE } \\
\hline \multirow[b]{2}{*}{$\begin{array}{l}\text { Process } \\
\text { Step }\end{array}$} & \multirow[b]{2}{*}{ Description } & \multirow[b]{2}{*}{$\begin{array}{c}\text { Leve! } 1 \\
\text { PFD } \\
\text { Reference }\end{array}$} & \multicolumn{3}{|c|}{ Time Duration (hr) } & \multicolumn{2}{|c|}{ MCO Contents } \\
\hline & & & $\begin{array}{c}\text { Normal } \\
\text { Processing }\end{array}$ & $\begin{array}{c}\text { Operat ional } \\
\text { Upsets }\end{array}$ & Accidents & Iemperature & Pressure \\
\hline $\begin{array}{l}14.17 a \\
14.27- \\
14.31\end{array}$ & $\begin{array}{l}\text { Remove MCO--Remove } \\
\text { vent hood, meve MHM to } \\
\text { pit, place MCO into } \\
\text { MHM, move MCO to } \\
\text { storage tube }\end{array}$ & $\begin{array}{l}P 8.5 \\
c 3.1\end{array}$ & 4 & $\begin{array}{l}\text { Connector } \\
\text { fajilure (leak } \\
\text { or blockage) } \\
\text {-single event } \\
\text { probability } \\
\text { - to; normal } \\
\text { processing } \\
\text { plus 2 hours }\end{array}$ & & $40^{\circ} \mathrm{C}$ & $\begin{array}{l}1100 \\
\text { torr } \\
\text { exiting } \\
\text { HCS }\end{array}$ \\
\hline
\end{tabular}




\section{OPERATIONS DESCRIPTION}

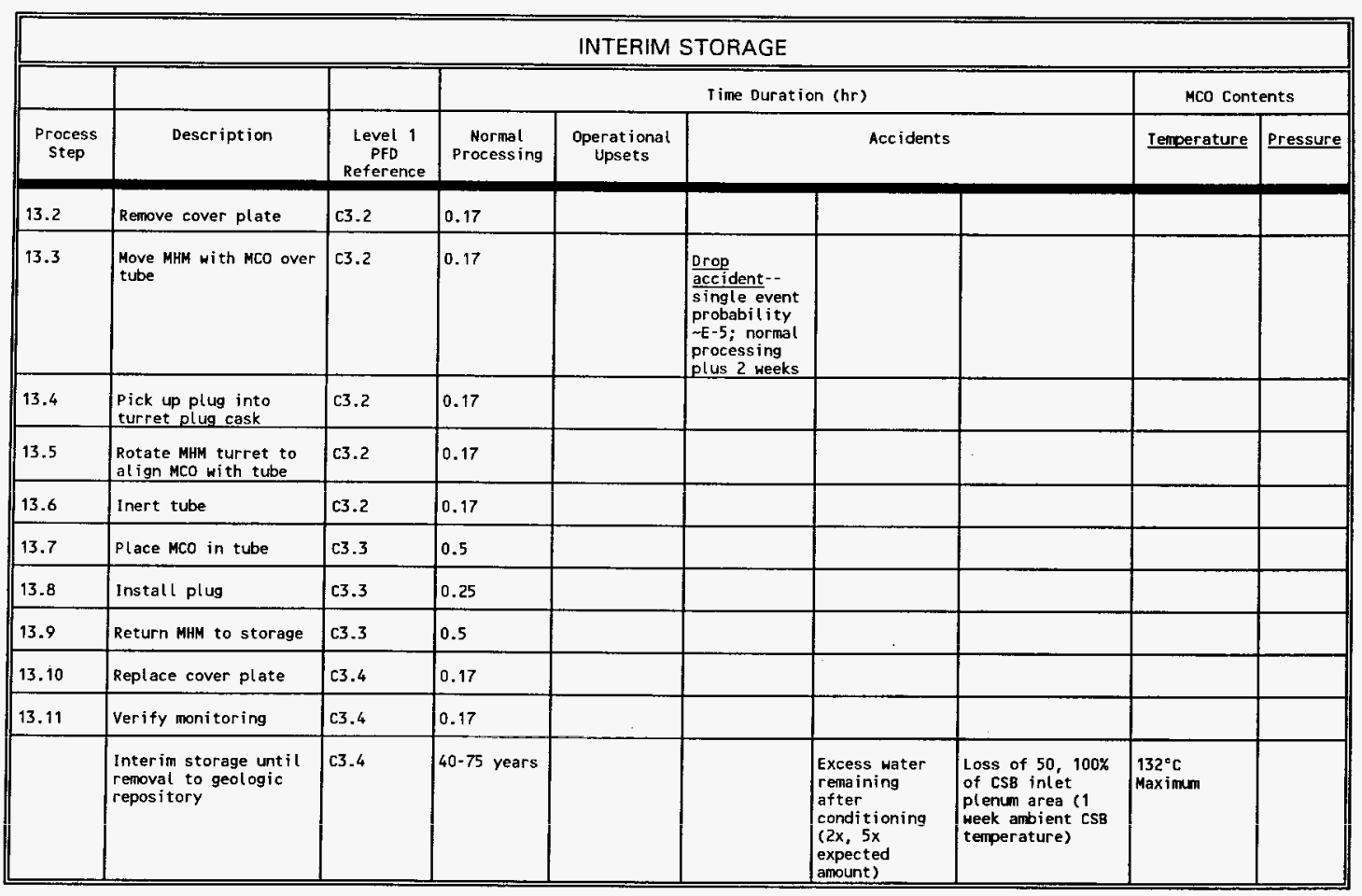

